\title{
Shopping centers em Curitiba: produção de novos espaços de consumo
}

\author{
Ana Helena Corrêa de FREITAS GIL
}

Dissertação de Mestrado: Curso de Mestrado em Geografia - UFPR

Data da defesa: 27 mar. 2003

Banca:

\author{
Wolf Dietrich Sahr (orientador) \\ Luís Lopes Diniz Filho \\ Maria Encarnação Beltrão Spósito
}

\section{RESUMO}

Vivemos em uma sociedade que tem como atividades dominantes a produção e consumo de mercadorias e serviços em grande escala, envolvendo as pessoas em um eterno círculo de ocas. A mercadoria assume um papel importante na estruturação da sociedade. Assim, o ato de consumir é antes de tudo uma ação social que se mantém por meio de uma atmosfera de consumo, em que todos têm algo para vender, seja a força do trabalho, sejam mercadorias concretas. Anthony Giddens (1989) analisa o espaço como um produto da ação humana. Nesta perspectiva, a transformação nas formas de comércio teve resultados diretos nas práticas das pessoas. Embutidos nessa evolução, aparecem no Brasil, nos anos oitenta do século XX, os grandes shopping centers, considerados "templos de consumo", que exercem forte influência na cidade em geral, e principalmente no perfil dos moradores e consumidores. O shopping center representa uma mistura entre o encontro social e comercial, incorporando em seu interior elementos históricos da antiga cidade, incentivando uma ação social imaginada e transformando a experi- ência dos consumidores para uma "nova cidadania". Na nossa pesquisa mostramos como o cenário dos shopping centers já é bastante diferenciado na atualidade, mostrando uma tipologia específica. Assim, os grandes empreendedores dos shopping centers procuram recriar elementos de tradição inventada, como algumas fachadas preservadas para manter o estilo clássico, como por exemplo, o Shopping Mueller, localizado em Curitiba. Nesta perspectiva, os shopping centers acabam competindo cada vez mais com os recursos de lazer realizados na própria cidade, tendo como vantagens um ambiente climatizado, limpo e relativamente seguro. Em conseqüência dessas reflexões, o shopping center é muito mais do que um empreendimento comercial. Ele participa numa forma de estruturação da sociedade pós-moderna que incorpora o consumismo como um método efêmero de criar identidades passageiras e exóticas.

\section{Palavras-chave:}

Shopping center, lazer, consumo, mercadoria. 